\title{
Fiscal (un)sustainability of the Croatian healthcare system: additional impact of the COVID-19 crisis
}

HRVOJE ŠIMOVIĆ, Ph.D.*

MAJA MIHELJA ŽAJA, Ph.D.*

MARKO PRIMORAC, Ph.D."

Article $^{* *}$

JEL: H51, I18

https://doi.org/10.3326/pse.45.4.5

\footnotetext{
"Some parts of the analysis presented in this article were previously published in Croatian language in Šimović and Primorac (2021). The authors would like to thank two anonymous referees for their useful comments and suggestions.

${ }^{* *}$ Received: June 8, 2021

Accepted: July 14, 2021
}

Hrvoje ŠIMOVIĆ

University of Zagreb, Faculty of Economics and Business, J. F. Kennedy 6, 10000 Zagreb, Croatia e-mail: hsimovic@efzg.hr

ORCiD: 0000-0002-4040-0899

Maja MIHELJA ŽAJA

University of Zagreb, Faculty of Economics and Business, J. F. Kennedy 6, 10000 Zagreb, Croatia e-mail: mmiheljaz@net.efzg.hr ORCiD: 0000-0003-1111-3345

Marko PRIMORAC

University of Zagreb, Faculty of Economics and Business, J. F. Kennedy 6, 10000 Zagreb, Croatia e-mail: mprimorac@efzg.hr ORCiD: 0000-0003-1629-3170 


\section{Abstract}

The main goal of this policy paper is to provide an overview of the basic problems that have impact on healthcare in Croatia and tend to make it unsustainable. The paper points out that the COVID-19 crisis has deepened and exacerbated the already existing problems of financing the health system. The analysis shows that Croatia swept under the rug systemic problems in financing healthcare and ultimately paid the price through frequent financial bailouts. Thus, in the period from 1994-2021, a total of HRK 23.9 billion was spent on bailing out the health service. On the other hand, the COVID-19 crisis can be seen as a chance to start solving the problem and implement certain reforms, both on the revenue and expenditure side of the health system.

Keywords: healthcare financing, financial bailouts, hospital debt, COVID-19, Croatia

\section{INTRODUCTION}

The fiscal sustainability of the healthcare system is a prerequisite for the long-term fiscal sustainability of every modern welfare state. Croatia's healthcare financing system has evident problems that are most often expressed through frequent recoveries of hospital debts, most often for pharmaceuticals. Wholesalers and pharmacies regularly recover debts only after threats to suspend the delivery of medicinal products and other medicinal goods. Although the Croatian Health Insurance Fund (CHIF) shows balanced financial operations in its reports, the Government is forced to cover part of the healthcare debt almost every year. So far, there have been 27 such bailouts in the period 1994-2021. On average, there is one bailout annually.

The debt of the health system is layered. The debt of hospitals to wholesalers for pharmaceuticals is the most important, but there are also other suppliers of medical equipment, materials, and diagnostics. An important component of the debt is liabilities to health care employees and numerous union lawsuits, which are either due or awaiting their moment in court. The big problem is that there are no official statistics on the amount and structure of healthcare debt, no clear documentation.

Despite numerous bailouts and reforms of the healthcare system, its debts continue to grow, and there are no indications of changes likely to prevent the emergence of new debts. During the COVID-19 crisis, several partial bailouts were undertaken. This indicates a problem with the (long-term) fiscal sustainability of the healthcare system. The systems for monitoring, cost management, and revenue and expenditure planning (budgeting) are obviously failing. Considering the circumstances of the COVID-19 pandemic, it can be expected that the financial challenges of the health system will be even more pronounced.

This paper aims to provide an overview of the basic problems that bring about the fiscal lack of sustainability of health care in Croatia. The article's main thesis is that the COVID-19 crisis is not the cause of financial problems in healthcare but only exacerbated them. The financial problems are a consequence of the already 
existing deep and systemic problems of Croatian healthcare. Indeed, the COVID19 crisis can serve as an opportunity to start reforms that will contribute to the long-term fiscal sustainability of the health system.

After the Introduction, the second part of the paper gives a short analysis of the concept of fiscal sustainability, with special emphasis on the Croatian case. In the third part, the sources of the fiscal unsustainability of the healthcare system in Croatia are analyzed. The fourth part discusses the impact of the COVID-19 crisis as an accelerator of financial health problems, but it can also be used as a spur for positive changes and reforms. The fifth part provides the conclusion.

\section{FISCAL SUSTAINABILITY OF HEALTHCARE}

\subsection{CONCEPT AND DEFINITION OF FISCAL SUSTAINABILITY IN HEALTHCARE}

In general, fiscal sustainability can be defined as the ability of a debtor to meet their financial obligations to creditors in the long term, with an acceptable balance of revenue and expenditure. Otherwise, debt becomes unsustainable if it grows faster than the debtor's ability to repay it. ${ }^{1}$ It is also assumed that fiscal sustainability exists if the existing public policies, especially those in the domain of fiscal policy and taxation, remain unchanged, as does the level of public debt (European Commission, 2014).

The above definition can be applied to narrower segments of the public sector and to the healthcare system as well. Although, due to the specificity of the public health system, the problem of fiscal sustainability should be viewed in a slightly different way. For the healthcare system, fiscal sustainability should not be seen as a goal but as a constraint that needs to be taken into account permanently. In order not to disrupt the level of healthcare and so compromise the health of the society, simple solutions for reducing healthcare debts, such as increasing revenues or cutting costs horizontally, should not be the primary focus. The system needs to be improved primarily by reducing cost-inefficient health interventions (OECD, 2015; Thompson et al., 2009).

\subsection{FISCAL UNSUSTAINABILITY OF THE CROATIAN HEALTHCARE SYSTEM: CONSTANT REFORMS AND CONSTANT DEBT ISSUES}

The Croatian healthcare system is continuously in debt. In view of the above definitions of fiscal sustainability and the fact that healthcare debts are continuously having to be repaid in Croatia, the Croatian healthcare system can reasonably be considered to be fiscally unsustainable. The problem is that there are no publicly available data on the amount and structure of the healthcare system's debt. In general terms,

\footnotetext{
${ }^{1}$ Fiscal sustainability is a narrower concept than financial sustainability. Since the Croatian health system is financed predominantly by public sources, the focus of the paper will be on fiscal sustainability and strengthening Croatian Health Insurance Fund (CHIF) revenues. However, there is a huge potential in increasing health care institutions' own revenues from private funds (e.g. clinical studies), which goes beyond the narrower "fiscal" framework and enters the domain of financial sustainability.
} 
the amount and structure of the debt can be found in various press releases or explanations of the Government or the Ministry of Health in Parliament.

The Minister of Healthcare reported in the Croatian Parliament that at the end of 2020, total healthcare debt was around HRK 13.83 billion. Of that, HRK 11 billion refers to debts to wholesalers (Croatian Parliament, 2020). Furthermore, the Government in the State Budget revision reported that Croatian healthcare generates around HRK 220 million in additional liabilities per month (Government of the RC, 2020a). Because of the threat of wholesalers to partially suspend the supply of pharmaceuticals and other medical goods, the Government implemented another healthcare system bailout. In a revision of the state budget in October 2020, an additional HRK 1.3 billion was earmarked for the bailout of health care institutions (Government of the RC, 2020b). Also, during March 2021, a so-called accelerated transfer of HRK 900 million to pharmacies and hospitals was agreed.

It is evident that the Government is prepared to cover a significant part of the overdue healthcare debt and underwrite its financial stability in the long term. The budget revision includes the fiscal effects of healthcare recovery and the economic crisis caused by COVID-19. The fact is that the budget deficit will be covered by debt, which is supported by the favorable situation on the financial market and historically low interest rates. It is an ideal time to take advantage of both the situation in the financial market and the social readiness for substantial reforms of healthcare, as well as to ensure long-term stabilization of the Croatian healthcare system.

From 1994 to 2021, Croatia spent HRK 23.9 billion on healthcare bailouts. ${ }^{2}$ Despite numerous reforms and financial bailouts, the healthcare system is experiencing constant financial difficulties, as pointed out by a number of other authors. Reforms implemented in the last 25 years have focused mainly on cost containment and less on inefficiencies that have been causing these financial problems. Reforms failed to address the crucial issues of financing, accessibility, and quality of health protection, although such actions managed to cope with the most acute financial problems in the short run. There are a number of papers the conclusions of which are in line with the previous statements (Vončina, Džakula and Mastilica, 2007; Zrinščak, 2007; Švaljek, 2014; Broz and Švaljek, 2014; Smolić, 2016; Radin, 2019).

\subsection{FUTURE OF HEALTHCARE EXPENDITURE AND IMPACT OF COVID-19 CRISIS}

The challenges of fiscal sustainability of healthcare will be even greater in the future. In the past, health spending has typically outpaced economic growth (Blecher et al., 2015). Certainly, the growth of healthcare expenditure cannot be held back in the long term, but the financing of the healthcare system can and must be more efficient (Mihaljek, 2014).

\footnotetext{
$\overline{{ }^{2} \text { Calculation is available later in this paper. See table } 3 .}$
} 
Although the growth of healthcare expenses has slowed down during the recent economic crisis, it is still higher than GDP growth. It is expected that this somewhat slower growth of healthcare expenses, compared to the historical average, will continue until 2030, but it will still be higher than the growth of GDP (Lorenzoni et al., 2019).

The above-presented projections were made prior to the COVID-19 pandemic. The COVID-19 crisis is expected to cause a drop in healthcare expenditure during 2020. Although significant resources (direct cost of COVID-19) are being invested in the fight against coronavirus, other non-urgent health care segments are underperforming. Patients avoid hospitals and clinics for fear of infection or placing an additional burden on health care professionals and the healthcare system in general (EIU, 2020; OECD/EU, 2020).

In Croatia, this decline was most felt in the operations of hospitals, which in 2020 generated $7 \%$ less revenue compared to 2021 . To facilitate health care institutions' process, the Croatian Health Insurance Fund (CHIF) paid hospitals around HRK 2 billion more than stated in their costs (CHIF, 2021).

On the other hand, the health sector was among the first recipients of additional government financial resources. Standard COVID-19-related budget measures in the health sector include: financing the procurement of specialized medical and personal protective equipment (PPE), expanding testing capacities, hiring of the additional workforce and bonus payments, support to hospitals and subnational governments, and contributions to vaccine development (OECD/EU, 2020; Blazey et al., 2021).

\section{Figure 1}

Central government additional COVID-19 health spending commitments per capita (between March and September 2020; EUR)

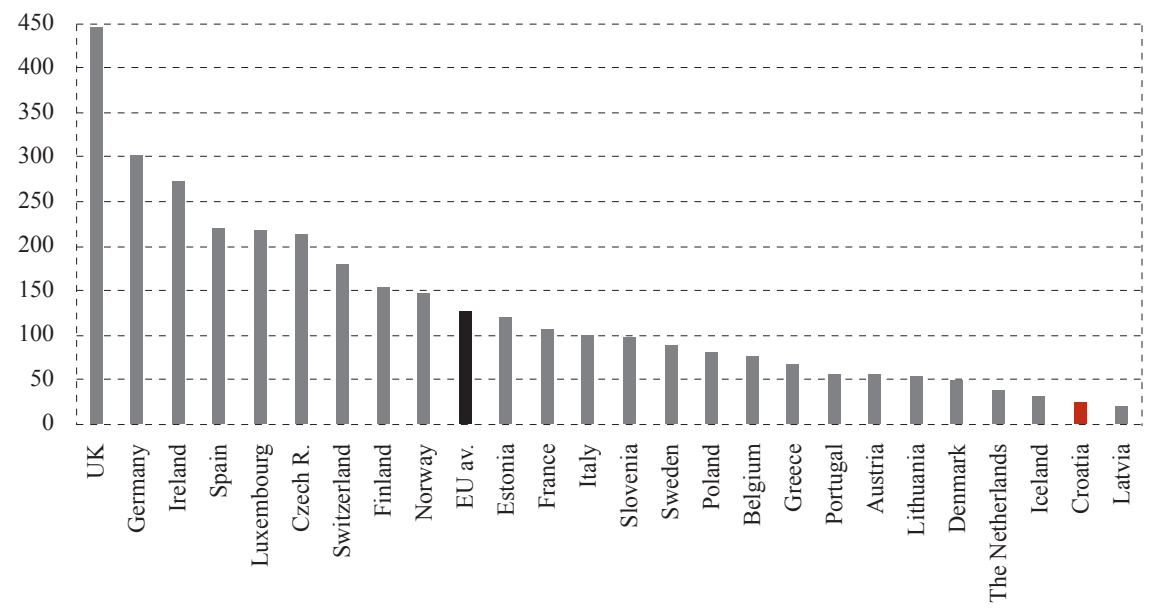

Source: OECD/European Union (2020: 44), for Croatia authors'calculations. 
The health sector was naturally among the first recipients of additional financial resources. Figure 1 shows that central government budgetary commitment to health system responses to COVID-19 ranged from almost EUR 450 per capita in the UK to around EUR 20 per capita in Latvia.

In the observed period between March and September 2020, Croatian commitments were around EUR 25 per capita, i.e., 766 million HRK (or 101 million EUR). In the last quarter of 2020, the cost of its large wave of infections doubled to HRK 1.24 billion HRK (164 million EUR) by the end of January 2021 (Krnić, 2020; 2021).

Healthcare expenditure is expected to recuperate at the end of the pandemic, i.e., in 2021. However, the corona crisis has also caused an economic crisis, which is reason enough to put additional fiscal pressure on the already limited public healthcare financing funds. It is to be expected that maintaining previous levels of funds allocated for healthcare will not be sufficient to meet the growing health needs resulting from the corona crisis (the so-called indirect or hidden costs of COVID-19). Namely, in the post-pandemic period, additional indirect healthcare costs are expected, resulting from postponed or canceled treatments, delayed detection of (especially oncological) diseases due to failures to visit a doctor, long-term and unknown health effects in those recovering from the coronavirus, and the consequences of prolonged staying indoors on both physical and mental health (Gheorghe et al., 2020; Coe et al., 2020).

Regardless of the COVID-19 health and economic crisis, healthcare expenditures are expected to increase in the future. The reasons are explained by demographic trends, new (and expensive) technologies in health care, income growth in society, and the institutional characteristics of health systems (Blecher et al., 2015).

Demographic trends, especially population aging, are often highlighted as the most important driver of rising healthcare costs. ${ }^{3}$ The elderly population is more prone to chronic diseases and multiple morbidities, which ultimately increases treatment costs. New technologies improve the scope and quality of health care services. This primarily relates to the provision of better but more expensive treatment for complex diseases.

Furthermore, with the growth of income in society, expectations from the (public) healthcare system also grow, and so does the scope of health care provided as part of mandatory health insurance. Lastly, healthcare systems' institutional characteristics have proven to be extremely important in explaining health spending growth. This primarily refers to the so-called Baumol effect or Baumol's cost disease: since the healthcare sector is a service sector and a predominantly labor-intensive

\footnotetext{
${ }^{3}$ Economic growth, specifically GDP per capita, has a positive effect on the efficiency of the health care sector, while the growing proportion of the elderly population reduces the coefficient of efficiency (Buljan, Deskar-Škrbić and Šimović, 2019).
} 
sector, it tends to increase the prices of its services even when the growth of prices is not associated with a growth in productivity. ${ }^{4}$

The above-listed are the general and specific (COVID-19) causes of the future growth of healthcare expenses that apply to most public healthcare systems across the world. Croatia's position is particularly challenging due to the healthcare system's existing large debt and its fiscal unsustainability. Because of that, the characteristics and problems of healthcare financing in Croatia should be analyzed in more detail.

\section{SOURCES OF FISCAL UNSUSTAINABILITY OF THE HEALTHCARE SYSTEM IN CROATIA}

There are several causes of financial problems in Croatian healthcare. In the following, we state the crucial problem that presents the genesis of the existing fiscal unsustainability.

\subsection{SIZE OF HEALTH EXPENDITURES AND THE DOMINANT ROLE OF PUBLIC FUNDING}

Expenditures for health services and healthcare of countries reflect the degree of their economic development as well as the development of their healthcare systems. Figures 2 and 3 show expenditures for healthcare in the EU as a percentage of GDP and per capita. These are the two most commonly used measures to show healthcare expenditure in a country. In general, more developed countries direct a larger part of their expenses into healthcare.

\section{Figure 2}

Health expenditure as a share of GDP, 2019 (or nearest year)

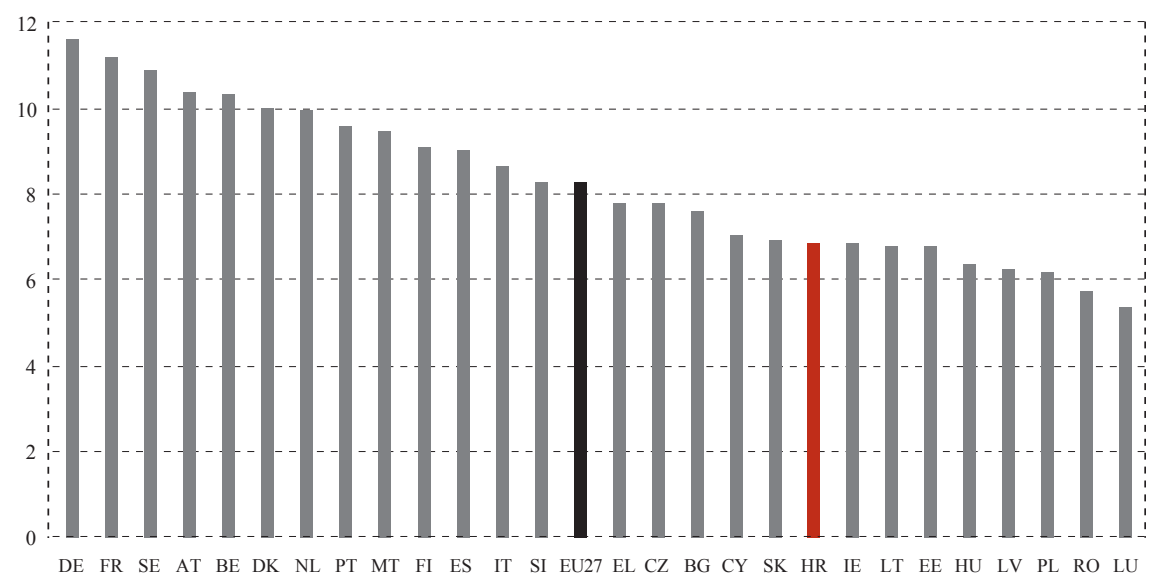

Source: OECD/European Union (2020).

\footnotetext{
${ }^{4}$ Precisely because such a conclusion is contrary to economic logic, it is called a "disease". Baumol (1967) came to this conclusion by analyzing why a sector of primarily public services, such as health and education, is experiencing a dichotomy of productivity and wages. He concluded that the service sector has low potential of generating innovation, as well as of improving productivity, because the substitution of labor by capital is almost impossible.
} 


\section{Figure 3}

Health expenditure per capita in EUR, 2019 (or nearest year, in thousands)
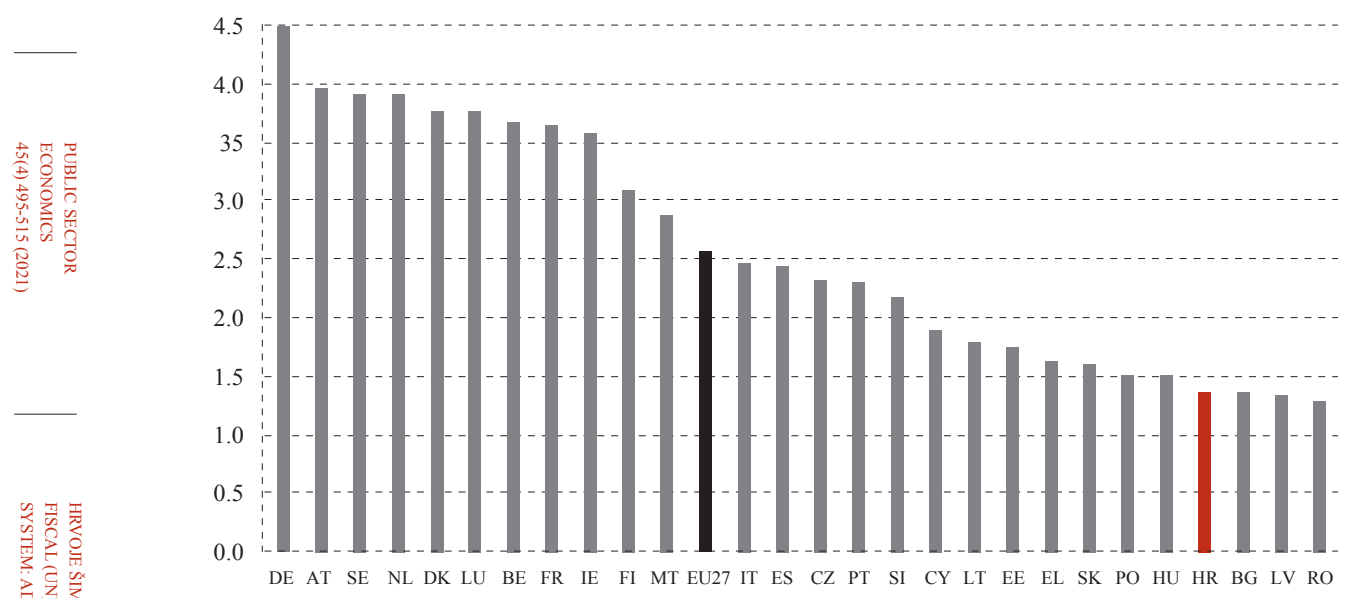

Source: OECD/European Union (2020).

Funds allocated to healthcare in Croatia are below the EU average. In 2019, healthcare expenditure amounted to $6.88 \%$ of GDP, while the EU average was $8.25 \%$ of GDP. In terms of per capita expenditures, Croatia's position is even worse. Croatia is below the EU average, spending EUR 1,361 per capita as against the EU average of EUR 2,572. These data should be considered with reserve, since the official statistics do not include the costs of covering healthcare debts.

EU healthcare systems are funded through various schemes. Public healthcare financing systems are predominant in EU countries. They include the mandatory healthcare insurance model and/or direct budgetary transfers to health care institutions. In Croatia, the mandatory insurance system is predominant, but part of health care is financed from the state budget. It is a combination of the Bismarck model of insurance based on contributions from salaries and the Beveridge model based on budgetary transfers.

The share of public funding in total healthcare expenditure in Croatia is slightly higher than the EU-28 average (OECD/European Union, 2020), the share of private healthcare financing thus being lower. This suggests that the increase in healthcare expenditure in the future should be financed to a greater extent through voluntary healthcare insurance or direct private payments and less through public funds.

\subsection{FAILURE TO COMPLY WITH THE LEGAL OBLIGATIONS OF THE STATE ITSELF IN FINANCING HEALTHCARE}

The key institution for implementing mandatory healthcare insurance is the Croatian Health Insurance Fund (CHIF). CHIF is a public institution whose primary goal is to provide funds for healthcare so that insured persons have adequate access to health services. 
The Mandatory Health Insurance Act (MHIA) (OG 80/13, 137/13, 98/19) (Art. 72 , item 1) defines different mandatory health insurance revenues, i.e., CHIF revenue (table 1). The problem is that it is not possible to determine the analytics for all types of reported revenues following the MHIA.

TABLe 1

Overview of realized revenue of CHIF in the period from 2015 to 2020 (million HRK)

\begin{tabular}{|c|c|c|c|c|c|c|}
\hline & 2015 & 2016 & 2017 & 2018 & 2019 & 2020 \\
\hline $\begin{array}{l}\text { Health insurance } \\
\text { contributions }\end{array}$ & $18,121.28$ & $18,468.68$ & $19,135.18$ & $19,904.22$ & $22,188.02$ & $21,042.81$ \\
\hline Budgetary income & $2,400.00$ & $2,588.95$ & $2,629.76$ & $3,100.00$ & $2,600.00$ & $3,769.21$ \\
\hline $\begin{array}{l}\text { Income under special } \\
\text { regulations (mostly } \\
\text { supplemental health } \\
\text { insurance) }\end{array}$ & $1,618.17$ & $2,650.80$ & $1,867.89$ & $2,004.79$ & $2,291.70$ & $2,451.01$ \\
\hline Property income & 14.52 & 14.02 & 17.36 & 15.19 & 12.53 & 7.76 \\
\hline Foreign aid - EU projects & 0.42 & 1.45 & 0.40 & 1.34 & 2.87 & 0.79 \\
\hline $\begin{array}{l}\text { Income from CES } \\
\text { (Croatian Employment } \\
\text { Service), professional } \\
\text { training without } \\
\text { employment }\end{array}$ & 0.62 & 0.43 & 0.91 & 0.48 & 0.00 & 0.00 \\
\hline $\begin{array}{l}\text { Income from services } \\
\text { provided }\end{array}$ & 0.05 & 0.37 & 0.86 & 1.16 & 1.30 & 1.99 \\
\hline $\begin{array}{l}\text { Income from sale of non } \\
\text { - financial assets }\end{array}$ & 0.75 & 0.50 & 0.65 & 0.72 & 1.90 & 3.11 \\
\hline Other income & 0.28 & 0.70 & 0.34 & 0.36 & 0.44 & 0.25 \\
\hline $\begin{array}{l}\text { Income from financial } \\
\text { assets and liabilities }\end{array}$ & 0.00 & 26.14 & 0.00 & 0.00 & 0.00 & $1,077.58$ \\
\hline In total & $22,156.10$ & $23,752.05$ & $23,653.35$ & $25,028.27$ & $27,098.76$ & $28,354.51$ \\
\hline
\end{tabular}

Source: CHIF (various years).

The problem arises with budgetary income. Budgetary income in the observed period ranges between HRK 2.4 and 3.7 billion. This budgetary income is generated in accordance with Articles 72 and 82 of the MHIA and Article 14 of the Voluntary Health Insurance Act (VHIA), and consists of:

- revenues from budget users who pay contributions for unemployed persons and persons deprived of their liberty by a decision of a competent court,

- additional contributions for insured persons receiving pensions under regulations on pension insurance and according to the Act on the Rights of Croatian Veterans (OG 121/17, 98/19),

- income from a special tax on tobacco products,

- income from premiums for supplemental health insurance policies for policyholders whose policies are covered by the state budget, and

- funds to cover the costs of healthcare for policyholders who have exercised this right at the expense of the state budget (Article 82 of the MHIA). 
When the Ministry of Finance transfers the mentioned funds, it fulfills the abovementioned legal provisions. Still, the exact amounts (analytics) of budgetary income cannot be determined from the financial reports. Additional confusion is created by significant revenue fluctuations in the past several years.

Another major problem is that it is often questioned whether the state transfers the correct (sufficient) amount based on budgetary income. Table 2 gives an estimate of the amount and structure of the budgetary revenues in the period from 2015 to 2020.

\section{TABLE 2}

Estimates of the amount and structure of budgetary incomes (million HRK)

\begin{tabular}{|c|c|c|c|c|c|c|}
\hline Budgetary income & 2015 & 2016 & 2017 & 2018 & 2019 & 2020 \\
\hline $\begin{array}{l}\text { Contributions for the } \\
\text { unemployed }\end{array}$ & $1,305.45$ & $1,124.94$ & 937.44 & 778.27 & 676.65 & 851.10 \\
\hline $\begin{array}{l}\text { Contributions for persons } \\
\text { deprived of their liberty }\end{array}$ & 10.71 & 11.05 & 11.37 & 10.18 & 12.48 & 10.92 \\
\hline $\begin{array}{l}\text { Additional contributions } \\
\text { for pension beneficiaries }\end{array}$ & 361.00 & 363.11 & 371.06 & 393.59 & 408.86 & 420.53 \\
\hline $\begin{array}{l}\text { Income from special } \\
\text { tax on tobacco }\end{array}$ & $1,339.93$ & $1,432.09$ & $1,399.69$ & $1,540.41$ & $1,636.71$ & $1,278.12^{*}$ \\
\hline $\begin{array}{l}\text { Premium for } \\
\text { supplemental health } \\
\text { insurance policy at the } \\
\text { expense of the State } \\
\text { Budget }\end{array}$ & 768.83 & 683.55 & 624.05 & 565.62 & 509.33 & 464.19 \\
\hline $\begin{array}{l}\text { Funds to cover the costs } \\
\text { of healthcare of insured } \\
\text { persons at the expense } \\
\text { of the State Budget }\end{array}$ & $1,060.22$ & 818.00 & $939.11 *$ & $939.11 *$ & 939.11* & $939.11^{*}$ \\
\hline $\begin{array}{l}\text { Total amount receivable } \\
\text { from the State Budget } \\
\text { (estimate) }\end{array}$ & $4,846.13$ & $4,432.74$ & $4,282.72$ & $4,227.19$ & $4,183.14$ & $3,963.97$ \\
\hline Budgetary income (paid) & $2,400.00$ & $2,588.95$ & $2,629.76$ & $3,100.00$ & $2,600.00$ & $3.769,21$ \\
\hline Difference & $-2,446.13$ & $-1,843.79$ & $-1,652.96$ & $-1,127.19$ & $-1,583.14$ & -194.76 \\
\hline
\end{tabular}

* Indicates estimated values.

Source: Authors' calculation.

According to budgetary income, in 2019 the state was supposed to transfer about HRK 4.22 billion to the CHIF, but the transferred amount was HRK 2.60 billion. This is a deficit of HRK 1.62 billion in the budgetary income for 2019. This problem is obvious in the period 2015-2019, while in 2020 it is not so pronounced due to higher state transfers due to the COVID crisis.

Due to the proclamation of the COVID-19 disease pandemic in 2020, the multiannual growth trend in the number of active insured persons, due to positive macroeconomic trends in previous years, was interrupted. This resulted in changes in the structure of total CHIF revenues (table 1). The share of revenues from contributions decreased significantly (from $81.88 \%$ to $74.21 \%$ ), and the share of budget 
revenues increased (from $9.59 \%$ to $13.29 \%$ ). To maintain the stability of the healthcare system, CHIF, in accordance with the Ministry of Health, accelerated the withdrawal of budget funds, which led to the planned annual limit of HRK 2.60 billion being reached in August 2020. Consequently, there was a temporary increase in CHIF obligations to pharmacies that were largely settled at the end of the year. This was enabled by an increase in revenue from the budget by HRK 0.5 billion in the last amendment to the CHIF plan and redistribution within the State Budget of Croatia, when an additional HRK 0.66 billion was remitted. These transfers, induced by the COVID-19 crisis, led to a decrease in the difference in total income that was supposed to be transferred to the CHIF according to Articles 72 and 82 of the MHIA and Article 14 of the VHIA.

The reason for obvious non-transparency in this segment remains unclear. The problem should be viewed from two sides. On the one hand, it is true that the state often financially bails out healthcare and that the amounts of the bailout exceed the legally prescribed funds by which mandatory health insurance should be supported. In recent years, the healthcare system has accumulated an average of approximately HRK 2.5 billion of new debt per year. On the other hand, if the state had allocated the total legal amount, the health system might not have been put in today's debt situation, which would have had a favourable effect on the many processes contributing to the quality of the healthcare system.

\subsection{HOSPITALS AS A GENERATOR OF HEALTHCARE DEBT}

Hospital costs and costs of medicines, including both particularly expensive drugs and prescription medicinal products, represent the two most significant healthcare items in Croatia. In most OECD countries, these hospital costs and costs of medicinal products should be focused on when establishing a system of controlling and budgeting healthcare expenditure, as opposed to other healthcare expenses (Vammalle et al., 2015).

Hospitals are the leading generators of healthcare debt. Hospitals, as public institutions, are obliged to disclose their financial reports publicly. Such availability of data provides insights into the status of due liabilities. At the end of 2020, total unpaid liabilities for material expenses amounted to around HRK 3.44 billion. The majority of material expenses refer to pharmaceuticals, medical consumables, and blood or blood products.

Figure 4 shows the structure of overdue debt according to overdraft days and to types of hospital facilities. The data show that $73 \%$ of the debt exceeds the legal payment period of 60 days. ${ }^{5}$ Clinical hospital centers $(\mathrm{CHC})$ and general hospitals (GH) are the main generators of debt because they are the largest health care institutions. A closer look at the structure of overdue liabilities by type of institution (figure 5) reveals that the main generators of overdue liabilities are general hospitals (GH) and clinical hospitals $(\mathrm{CH})$, in which debts of over 360 days are dominant.

\footnotetext{
${ }_{5}^{5}$ According to the Act on Financial Operations and Pre-Bankruptcy Settlement (OG 108/12, 144/12, 81/13, $112 / 13,71 / 15,78 / 15)$.
} 


\section{Figure 4}

Structure of due liabilities of hospitals for material expenses at the end of 2020

a) Overdraft days

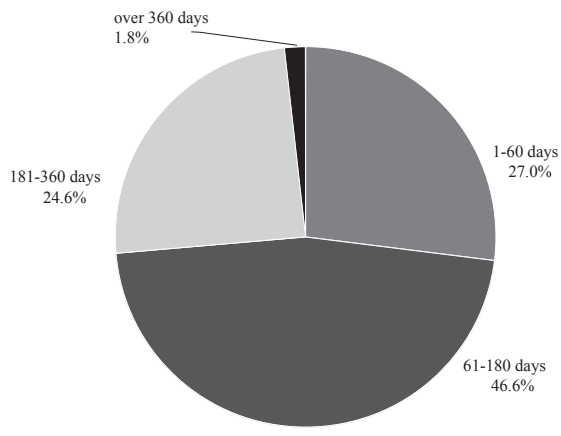

b) Type of institution

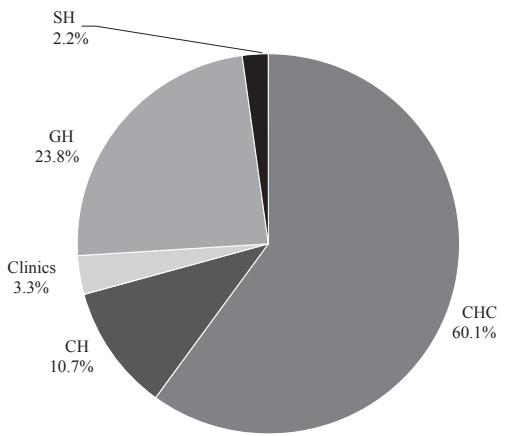

Note: CHC - Clinical Hospital Center, CH - Clinical Hospital, GH - General Hospital, SH - Special Hospital. Health resorts, health care centers, and institutes are omitted from this part of the analysis. At the time of this analysis (May 2020), the CHC Sestre Milosrdnice and the Clinic for Children's Diseases did not make public the data on due liabilities for 2020, so the data for 2019 was used in analysis.

Source: Authors'work according to the Reports on liabilities of individual hospitals, hospital websites.

\section{FiguRe 5}

Structure of due liabilities by type of institution (2020), in percent

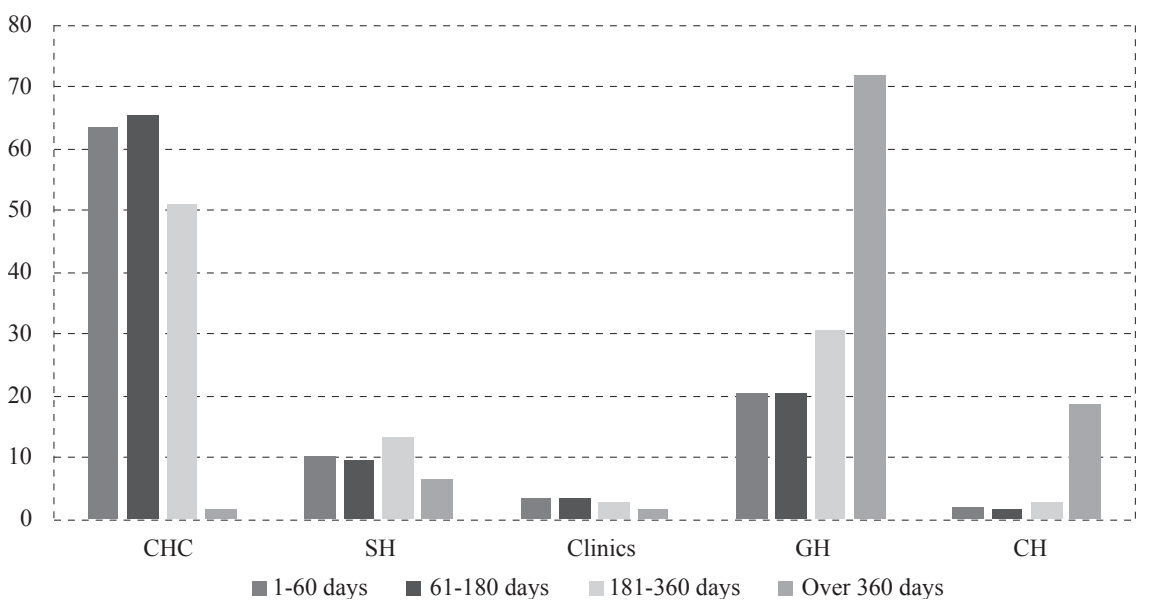

Note: CHC - Clinical Hospital Center, CH - Clinical Hospital, GH - General Hospital, SH Special Hospital. Health resorts, health care centers, and institutes are omitted from this part of the analysis. At the time of this analysis (May 2020), the CHC Sestre Milosrdnice and the Clinic for Children's Diseases did not make public the data on due liabilities for 2020, so the data for 2019 was used in analysis.

Source: Authors'work according to the Reports on liabilities of individual hospitals, hospital websites. 


\subsection{HOSPITAL LIMIT POLICY, THE ROLE OF THE CROATIAN HEALTH INSURANCE FUND, AND THE LACK OF STANDARDS}

In addition to medicinal product consumption and better coordination of primary and hospital health care, fiscal sustainability of healthcare includes better management of, in particular, hospital spending in terms of increasing the quality and efficiency of the hospital system. Hospital spending makes up the largest segment of healthcare spending and generates the majority of its debt. Accordingly, there is a perception that the crucial problems of health care are in the system of hospital health care. This problem, however, cannot be solved only through the hospital healthcare system reform without reforming other subsystems, such as primary health care. Nevertheless, the hospital system has a problem in the context of financing because it cannot significantly impact the level of current revenues and expenditures of business activities. As independent business subjects, hospitals enter contracts with CHIF, and in this manner, by conducting their business activities, they achieve revenues and expenditures.

On the other hand, hospitals have no influence on the pricing of services or programs (limits), which the Administrative Council of CHIF unilaterally determines. CHIF primarily determines prices based on the available financial resources, not on cost price, or economic price, of a certain health service. After considering the costs of medical devices, implants, and medical transport of patients, a hospital is often forced to operate with a loss because many of the services cost more than the limits determined by CHIF.

Moreover, there are elements on the expense side of hospitals and other health care institutions that increase exogenously, and that are, on the other hand, not accompanied by adequate growth of hospital limits or correction of the prices of health care services. This primarily refers to personnel costs (salaries) and other material rights comprising the majority of the total expenses of health care institutions, which are the subject of negotiations between the Government and the union(s) through collective agreements. For example, in UHC Zagreb, personnel costs in 2019 increased by $8.1 \%$ vs. 2018. This growth trend was also noticeable in 2020, and additional growth of salaries has been announced due to extra engagement during the COVID-19 crisis.

The agreement between CHIF and hospitals defines a unique price for the programs (a limit) for each hospital. ${ }^{6}$ The limit includes all the hospital activities, i.e., there are no sub-limits for individual activities. Efficient management is not possible because it is not possible to assess business success per individual activity (cost center).

One of the healthcare system reform priorities should be better definitions of (economic) prices of health services. This includes several associated reforms, such as

${ }^{6}$ The methodology of calculating the maximum amount of funds is unknown, which does not improve the transparency of this system. 
a revision of prices of health services, the definition of centers of excellence, the description of standard treatments, and a good connection with the public procurement system. In a relatively short term, a task force can be formed at the level of the Ministry of Health, which would revise the prices of health services (DRG, $\mathrm{HDs})^{7}$, taking into account the real input costs expressed through the prices of medical products and material obtained through the process of public procurement.

Ultimately, in order to define a realistic economic price for health services it is necessary to specify a standard of treatment for individual diagnoses. ${ }^{8}$ This is closely connected to introducing the concept of above-standard care into the healthcare system, which was explained among the measures for increasing healthcare revenue. The Ministry of Health (specifically, the former Agency for Quality and Accreditations in Health and Social Care) can assist in defining both standard and above-standard care. The question remains as to why, as with medicinal products, we do not have lists A and B for medical devices and implants. The basic standard (A) would be entirely covered by mandatory health insurance, while above-standard care (B) could be realized through direct payment or supplemental health insurance policy. It is neither necessary nor suggested that the lowest price criteria be used to define the basic standard. The medical profession is very familiar with trends in treating certain diseases and physical defects. The point is that the defined standard does not increase the patient's health risk, i.e., at the same time, we optimize the ratio of the quality and price of services.

\section{COVID-19 PANDEMIC AS AN ACCELERATOR OF FISCAL \\ UNSUSTAINABILITY AND REFORMS}

The COVID-19 crisis can be observed in two ways. First, it has undoubtedly accelerated the financial problems of the healthcare system. The focus is on healthcare debt, which has been growing for years. Second, any crisis is a chance for reform. The COVID-19 crisis has contributed to a better understanding of the financial problems of the health system. The public increasingly emphasizes the need for long-term solutions to the problem and the need for systematic reforms.

\subsection{FINANCIAL BAILOUTS AS A MODEL OF SWEEPING PROBLEMS UNDER THE RUG}

We mentioned earlier that the existing concept of the lack of fiscal sustainability in the health system is being addressed through regular financial bailouts. Table 3 shows the history of financial bailouts of the Croatian healthcare system. In the period 1994-2021, HRK 23.9 billion of debt was repaid through different bailout models. In recent years, the recovery model was implemented predominantly through state budget transfers, either to the CHIF or health care institutions (mainly hospitals). Thus, the dominant debt generator is the outstanding liabilities to drug wholesalers.

\footnotetext{
${ }^{7}$ Diagnostic Related Grouping, Hospital Days.

${ }^{8}$ For example, what is the standard hip replacement during hip surgery or the standard synthetic mesh for hernia surgery, or the standard stent for treating blockage or narrowing of cardiac arteries.
} 
TABLE 3

Financial recoveries of the Croatian healthcare system, 1994-2021 (million HRK)

\begin{tabular}{|c|c|c|}
\hline Year & Financial bailouts & Amount \\
\hline 1994 & Financial bailout agreement with health institutions & 214.84 \\
\hline 1994 & Agreement with wholesalers - paid obligations for pharmaceuticals & 62.13 \\
\hline 1998 & $\begin{array}{l}\text { Settlement of due obligations towards health care institutions - } \\
\text { from the Budget }\end{array}$ & 593.00 \\
\hline 1999 & Commitments of hospital suppliers & 845.37 \\
\hline 1999 & Budget transfer for suppliers & 792.02 \\
\hline 1999 & Short-term loan from a bank & 120.00 \\
\hline 1999 & Promissory note issued for pharmacy debt (debt older than 90 days) & 244.98 \\
\hline 1999 & Pliva takes over CHIF debt to pharmacies & 375.21 \\
\hline 2000 & CHIF issues bonds & $1,668.67$ \\
\hline 2000 & Short-term loan & 115.00 \\
\hline 2001 & Collection of receivables from CHIF & 750.37 \\
\hline 2001 & Short-term loan & 108.00 \\
\hline 2002 & Loan & 820.00 \\
\hline 2003 & Loan & 410.00 \\
\hline 2004 & $\begin{array}{l}\text { Transfer to hospitals from the Ministry of Finance (State Budget) } \\
\text { for suppliers }\end{array}$ & 533.01 \\
\hline 2005 & $\begin{array}{l}\text { Agreement with Zagrebačka banka on taking over overdue } \\
\text { receivables for pharmaceuticals }\end{array}$ & 808.70 \\
\hline 2007 & $\begin{array}{l}\text { Sale of shares owned by CHIF through the Privatization Fund - } \\
\text { paid orthopedic devices and aids }\end{array}$ & 90.00 \\
\hline 2007 & Obligations to suppliers - CHIF & $1,200.00$ \\
\hline 2008 & $\begin{array}{l}\text { Liabilities of hospitals to suppliers of pharmaceuticals } \\
\text { and medical supplies }\end{array}$ & 500.00 \\
\hline 2012 & Assignment agreement & 465.03 \\
\hline 2013 & Assignment agreement & $3,062.06$ \\
\hline 2014 & Assignment agreement & $3,200.00$ \\
\hline 2017 & Budget transfer to hospitals to settle debt to wholesalers & 200.00 \\
\hline 2019 & Extraordinary payment of CHIF to wholesalers for overdue debt & 500.00 \\
\hline 2020 & Budget transfer to CHIF for wholesalers debt & 500.00 \\
\hline 2020 & State Budget amendment (additional revenues for CHIF) & $1,300.00$ \\
\hline 2021 & $\begin{array}{l}\text { Budget transfer to CHIF ( } 600 \text { million for pharmacy debt } \\
\text { and } 300 \text { million for hospitals) }\end{array}$ & 900.00 \\
\hline 2021 & $\begin{array}{l}\text { Budget transfer to CHIF for pharmacy debt and hospital debt } \\
\text { (installments of } 900 \text { million in April, May and June, plus a state } \\
\text { budget amendment of an additional } 895 \text { million) }\end{array}$ & $3,595.00$ \\
\hline Total & & 23,973.39 \\
\hline
\end{tabular}

Source: Authors for the period after 2017 and Jurković (2018) for the period until 2017.

It should be noted that various reforms were continuously implemented in the observed period, and were supposed to contribute to the fiscal sustainability of healthcare. For example, since 2015 CHIF has not been in the State Treasury system. No reform has contributed to the financial sustainability of the system. In fact, in recent years, financial bailouts have become more frequent and more generous. 
Furthermore, official statistics do not show expenditures for healthcare bailouts. This means that Croatia allocates more funds than indicated by official statistics (figures 2 and 3). On average, the state bails out healthcare with an additional $0.65 \%$ of GDP annually while at the same time generating new outstanding debts.

\subsection{POSSIBLE REFORMS AND SOLUTIONS TO THE PROBLEM}

The problem can be solved through either the revenue or the expenditure side. An increase in income (taxes or contributions) can be implemented in a relatively short time. Expenditure-side reforms require a more extended period. It should be emphasized that - even though the potential possibilities of increasing income are listed and explained below - it is imperatively necessary to reduce the expense side of the healthcare budget. The healthcare system must change internally in terms of organization and management. No new debts should be generated. Eventually new debts should be considered only if they increase the efficiency of the healthcare system in the context of the quality and availability of health care.

Furthermore, increasing the revenues of the healthcare system is more in the domain of the Ministry of Finance and less in the domain of the Ministry of Health. As the strengthening of health income is mainly in the domain of the Ministry of Finance, re-allocating expenses and increasing the efficiency of healthcare is the sole responsibility of the Ministry of Health and other segments of the public healthcare system, such as CHIF and health institutions.

Increasing contributions, especially in the context of the COVID-19 crisis, is not a prudent measure. The current contribution rate of $16.5 \%$ is already high. Increasing the health contribution rate would further contribute to the increase in labor costs. An increase in other CHIF revenues is a more apparent measure. One possibility is to increase the share of excise duty on tobacco. Currently, $35 \%$ of the excise tax on tobacco revenue belongs to CHIF as part of "budgetary income". According to the World Health Organization, the tobacco tax is the most common form of sin tax or public health tax (Cashin, Sparkes and Bloom, 2017: 24). Also, it is generally considered that the cost of treating smokers is much higher than the financial benefits that the state derives from tobacco taxes. Inclusion of other excise duties (e.g., alcohol) and/or introduction of new special sin taxes (e.g., sugar, fats, etc.) as CHIF income may be considered.

Furthermore, it is necessary to find new ways to increase income from supplemental health insurance. The emphasis should be on increasing the number of people with additional health insurance and not raising policy prices. In particular, it is necessary to encourage 1.87 million insured persons who do not have SHI to take out a supplemental health insurance policy. The possible change refers to an increase of the HRK 2,000 limit per one issued invoice for provided health care. This would encourage people to take out supplemental insurance.

Public sources of healthcare financing are limited, and it is necessary to increase health care institutions' revenues. $\mathrm{R} \& \mathrm{D}$ and clinical trials are often mentioned as 
an essential alternative source of health system financing. Croatia lags behind other EU countries in the number of clinical trials. The number of studies indirectly reveals the amount of investments. In Croatia, only EUR 40 million, or EUR 9.81 per capita, is annually invested in R\&D. For comparison, in Slovenia, EUR 86 per capita is invested in R\&D, in Hungary EUR 24 per capita, whereas Denmark invests EUR 280 per capita, and Belgium as much as EUR 311 per capita annually (EPFIA, 2020). It is indisputable that there is room to strengthen our own revenues through $\mathrm{R} \& \mathrm{D}$, clinical trials, and more.

The measures on the expense side are restricted by the fact that most of the positive fiscal effects can only be realized in a longer time frame and that a fiscal effect assessment is not possible in most cases. Various measures have been proposed that can positively impact fiscal sustainability, such as strengthening prevention and primary health care and optimizing pharmaceuticals consumption and payment according to treatment outcome. An important segment with the potential for significant results is the coordination of hospital treatment and primary health care, where health care digitalization plays a significant role. ${ }^{9}$

The most critical segment associated with the expense side refers to establishing a partnership between health care institutions and CHIF, so that health care institutions have more say in managing their own incomes and expenses. This means a more straightforward definition and implementation of payment per economic price of health care services, the definition of treatment standard, and centers of excellence in the hospital system.

There is a whole range of measures and areas based on which the healthcare system can be improved, and its fiscal sustainability ensured. Some of these measures were recognized in the National Strategy for Health Care Development for 2012-2020 and national plans for hospital development (Government of the RC, 2012; Ministry of Health, 2018). Furthermore, "dual" financing should be implemented for the survival of regional hospitals that operate in a political and social dimension. Dual financing involves co-financing of operative expenses by the founder, i.e., the county or the city/town. Currently, funding is exclusively in the domain of CHIF.

\section{CONCLUSION}

The problem of the fiscal sustainability of the Croatian healthcare system is evident. For a healthcare system to provide efficient and high-quality health care, it requires adequate financing, i.e., it must be fiscally sustainable.

Croatia is among the leading countries in the EU in terms of health care availability. A large part of the population is covered by mandatory health insurance and has the right to health care. But only a third of insured persons are actively insured

\footnotetext{
${ }^{9}$ For general measures see Blecher et al. (2015). For specific measures for Croatia see Šimović and Primorac (2021).
} 
people, upon whose work contributions for health insurance are paid. Furthermore, a range of factors influences the growth of healthcare costs, such as demographic trends, population aging, advancements in medical technology, and medicinal products requiring significant investments and generating high costs. The current impact of the COVID-19 pandemic should also be noted. We can expect COVID-19 to have an additional impact on the growth of healthcare costs through various hidden and indirect costs.

The amounts paid for financial bailouts should be turned into regular income. In relative terms (as a percentage of GDP), and excluding private health expenditures, resources allocated for healthcare in Croatia are below the EU average. Furthermore, Croatia is among the EU countries with the lowest allocations for healthcare, in terms of allocation per capita. This picture, however, is not entirely accurate because the official statistics do not include the costs of covering healthcare debts. Considering that the allocated amount is higher than the one recorded in the official statistics, there are legitimate demands for restructuring the healthcare system on the inside in terms of organization and management to achieve much better results with the resources received.

In addition to analyzing the present condition and identifying key problems, this paper indicates some measures to strengthen the fiscal sustainability of the Croatian healthcare system on both the revenue and the expenditure side. Some of the measures are already known. In addition to the political will, education and raising awareness about the importance of this problem are also necessary. Resolving this problem requires better understanding and cooperation between the Ministry of Finance and the Ministry of Health regarding objective budgetary restrictions and the financing of this complex and necessary healthcare system.

\section{Disclosure statement}

All authors state that they do not have any financial or other substantive conflict of interest. 
1. Act on Financial Operations and Pre-Bankruptcy Settlement, OG 108/12, 144/12, 81/13, 112/13, 71/15, 78/15.

2. Act on the Rights of Croatian Veterans, OG 121/17, 98/19.

3. Baumol, W. J., 1967. Macroeconomics of Unbalanced Growth: The Anatomy of Urban Crisis. American Economic Review, 57(3), pp. 415-426.

4. Blazey, A. [et al.], 2021. Adaptive Health Financing: Budgetary and Health System Actions to Combat COVID-19. OECD Journal on Budgeting, 21(1), pp. 1-27. https://doi.org/10.1787/69b897fb-en

5. Blecher, M. [et al.], 2015. Fiscal sustainability of health systems - Why is it an issue, what can be done? In: Fiscal Sustainability of Health Systems: Bridging Health and Finance Perspectives. Paris: OECD, pp. 23-44. https://doi. org/10.1787/9789264233386-5-en

6. Broz, T. and Švaljek, S., 2014. Financiranje zdravstva u Hrvatskoj: od reforme do reforme. In: M. Vehovec, ed. O zdravstvu iz ekonomske perspektive. Zagreb: Ekonomski institut, pp. 51-75.

7. Buljan, A., Deskar-Škrbić, M. and Šimović, H., 2019. Determinants of Public Health Care, Education and Administration Efficiency in Central, Eastern and South Eastern Europe. Hrvatska i komparativna javna uprava, 19(4), pp. 537563. https://doi.org/10.31297/hkju.19.4.2

8. Cashin, C., Sparkes, S. and Bloom, D., 2017. Earmarking for Health: From Theory to Practice. Health Financing Working Paper, No. 5.

9. CHIF (various years). Business Report of the Croatian Health Insurance Institute. Zagreb: Croatian Health Insurance Fund.

10. CHIF, 2021. Report on the operations of the Croatian Health Insurance Institute for 2020. Zagreb: Croatian Health Insurance Fund.

11. Coe, E. [et al.], 2020. Understanding the hidden costs of COVID-19's potential impact on US healthcare. McKinsey \& Company.

12. Croatian Parliament, 2020. Izvješće Odbora za zdravstvo i socijalnu politiku s rasprave o temi: "Stanje u zdravstvu - dugovi". Zagreb: Croatian Parliament.

13. EIU, 2020. Covid-19: the impact on healthcare expenditure. London: Economist Intelligence Unit.

14. EPFIA, 2020. The Pharmaceutical Industry in Figures: Key Data 2020. Brussels: European Federation of Pharmaceutical Industries and Associations.

15. European Commission, 2014. Identifying fiscal sustainability challenges in the areas of pension, health care and long-term care policies. European Economy Occasional Papers, No. 201.

16. Gheorghe, A. [et al.], 2020. COVID-19 and Budgetary Space for Health in Developing Economies. Center for Global Development Note, July 2020.

17. Government of the RC, 2012. National health care strategy 2012-2020. Zagreb: Government of the RC and Ministry of Health.

18. Government of the RC, 2020a. Obrazloženje Prijedloga izmjena $i$ dopuna Državnog proračuna Republike Hrvatske i financijskih planova izvanproračunskih korisnika za 2020. godinu. Zagreb: Government of the RC. 
19. Government of the RC, 2020b. Marić: Država će izmiriti obveze prema veledrogerijama. Zagreb: Government of the RC.

20. Jurković, D., 2018. Kvalitetan i održiv zdravstveni sustav u Hrvatskoj. Presentation. 120. Kongres poslodavaca u zdravstvu Hrvatske.

21. Krnić, I., 2020. Korona nagrizla zdravstveni budžet: Trošak epidemije u 2020. za HZZO će biti milijardu kuna. Jutarnji.hr, December 7, 2020.

22. Krnić, I., 2021. Eskalacija troška korone: U 7 tjedana izdaci za liječenje i bolovanja su se udvostručili. Jutarnji.hr, January 25, 2021.

23. Lorenzoni, L. [et al.], 2019. Health spending projections to 2030: New results based on a revised OECD methodology. OECD Health Working Paper, No. 110. https://doi.org/10.1787/5667f23d-en

24. Mandatory Health Insurance Act, OG 80/13, 137/13, 98/19.

25. Mihaljek, D., 2014. Kako financirati zdravstvo u doba financijske krize? In: M. Vehovec, ed. $O$ zdravstvu iz ekonomske perspektive. Zagreb: Ekonomski institut, pp. 29-50.

26. Ministry of Health, 2018. National Development Plan for Clinical Hospital Centers, Clinical Hospitals, Clinics and General Hospitals in Croatia 20182020. Zagreb: Ministry of Health.

27. OECD, 2015. Fiscal Sustainability of Health Systems: Bridging Health and Finance Perspectives. Paris: OECD. https://doi.org/10.1787/9789264233386-en

28. OECD/European Union, 2020. Health at a Glance: Europe 2020: State of Health in the EU Cycle. Paris: OECD. https://doi.org/10.1787/82129230-en.

29. Radin, D., 2019. Health Policy in Croatia: A Case of Free Falling. In: Z. Petak and K. Kotarski, eds. Policy-Making at the European Periphery, New Perspectives on South-East Europe: The Case of Croatia. Cham: Springer International Publishing, pp. 247-264. https://doi.org/10.1007/978-3-319-73582-5_13

30. Šimović, H. and Primorac, M., 2021. Fiskalna održivost hrvatskog zdravstvenog sustava. Fiscus, No. 10.

31. Smolić, Š., 2016. Zdravstveni sustav. In: A. Obadić and J. Tica, eds. Gospodarstvo Hrvatske. Zagreb: Ekonomski fakultet, pp. 471-508.

32. Švaljek, S., 2014. The Recent Health Reform in Croatia: True Reforms or Just a Fundraising Exercise? Health Policy, 115(1), pp. 36-43. https://doi. org/10.1016/j.healthpol.2013.09.010

33. Thompson, S. [et al.], 2009. Addressing financial sustainability in health systems, Policy summary prepared for the Czech European Union Presidency Ministerial Conference on the Financial Sustainability of Health Systems in Europe. Copenhagen: WHO.

34. Vammalle, C. [et al.], 2015. Budgeting practices for health in OECD countries. In: Fiscal Sustainability of Health Systems: Bridging Health and Finance Perspectives. Paris: OECD, pp. 79-113.

35. Voluntary Health Insurance Act, OG 85/06, 150/08, 71/10, 53/20. 
36. Vončina, L., Džakula, A. and Mastilica, M., 2007. Health care funding reforms in Croatia: a case of mistaken priorities. Health Policy, 80(1), pp. 144-157. https://doi.org/10.1016/j.healthpol.2006.02.016

37. Zrinščak, S., 2007. Zdravstvena politika Hrvatske. U vrtlogu reformi i suvremenih društvenih izazova. Revija za socijalnu politiku, 14(2), pp. 193-220. https://doi.org/10.3935/rsp.v14i2.697 